\title{
Cost variation analysis among different antidepressant drugs used to treat major depressive disorder
}

\author{
Raman K. Tripathi ${ }^{1}$, Shamsher Singh ${ }^{2, *}$ \\ ${ }^{1}$ Scholar, Dept. of Pharmacy Practice, ${ }^{2}$ Associate Professor, Dept. of Pharmacology, I.S.F College of Pharmacy, Moga, Punjab, \\ India
}

*Corresponding Author:

Email: shamshersinghbajwa@gmail.com

\begin{abstract}
The Indian pharmaceutical industry produces drugs on a large scale and standing on $3^{\text {rd }}$ rank bases on the scale of production. Due to this huge scale of production they produce all of the drugs and there are many brands of the same drugs. These brands are having competition between them so cost variation could be seen.

Aim: The aim of our study is to find out the cost variation among the antidepressant drugs used in the treatment of major depressive disorder (MDD) that are the tricyclic antidepressants (TCAs), selective serotonin reuptake inhibitors (SSRIs), monoamine oxidase inhibitors (MAOIs), the serotonin-norepinephrine reuptake inhibitors (SNRIs).

Materials and Method: The anti-depressant drugs that are manufactured by various Indian pharmaceutical industries are analyzed in that study. The data was collected by the authors from "Current Index of Medical Specialties" (CIMS) online edition, www.drugs.com and Mobile Application of National Pharma Pricing.

Results: There are 15 anti-depressant drugs with 63 formulations are available in the marked of India with 1173 brands. Among all the antidepressant drugs, the highest cost ratio and percentage cost variation was found for the fluvoxamine $100 \mathrm{mg}$ followed by amitriptyline $50 \mathrm{mg}$ Nortriptyline $20 \mathrm{mg}$ and clomipramine $75 \mathrm{mg}$. The highest numbers of brands are for escitalopram $10 \mathrm{mg}$ followed by Sertraline $50 \mathrm{mg}$ and Paroxetine $37.5 \mathrm{mg}$.

Conclusion: It is concluded that there is very high cost variation among the marked preparations of antidepressant drugs used to treat Major depressive disorder (MDD).
\end{abstract}

Keywords: Major Depressive Disorder (MDD), Tricyclic antidepressants (TCAs), Selective serotonin reuptake inhibitors (SSRIs), monoamine oxidase inhibitors (MAOIs), The serotonin-norepinephrine reuptake inhibitors (SNRIs), Cost ratio, Percentage cost variation.

\section{Introduction}

There are many pharmaceutical industries in India. The pharmaceutical industries of India are on $3^{\text {rd }}$ rank on the bases of volume and on the $14^{\text {th }}$ rank according to the value. With this large scale of production these industries manufactures all of the drugs and different brands of the same drugs are available in market. ${ }^{14}$ These brands come with competition with each other. So, they are having variety of cost variation among the marketed preparation of drugs.

This study has done to analyze the cost variation of the marketed brands of four groups or class of Antidepressant drugs that are used in the treatment of major depressive disorder (MDD) that are tricyclic antidepressants (TCAs), selective serotonin reuptake inhibitors (SSRIs), monoamine oxidase inhibitors (MAOIs), serotonin-norepinephrine reuptake inhibitors (SNRIs). In these classes of antidepressant drugs wide range of cost variation is detected in the marketed brands. ${ }^{11}$

Major depressive disorder (MDD), which also referred as depression is a disorder of brain that is characterized when a person is having low mood since at least two weeks and that is present over most of the situations. ${ }^{4}$ It is mostly shown by a lost or less interest in enjoyable and playful activities, low self-esteem and sometime sudden pain without any reason. People can sometimes hear or see the false things that aren't even there. The periodic condition of the depression could also be seen in some people who are separated by years but they are normal and other than these people show symptoms every time. ${ }^{6}$ MDD can affect a person's life negatively by interfering personal, school, work as well as habits of eating, general health and also sleeping problems. In the adult's death $2-7 \%$ of the deaths are due to MDD leading to suicide and more than $60 \%$ of the people that died by suicide also had some kind of depression or mood disorder. ${ }^{13}$

The cause of the MDD is not only based of few factors instead it is a combination of environmental, genetic and psychological factors. Risk factors of MDD includes big life changes, family history related to depression, some medications, chronic problems related to health and drug addiction or substance abuse. ${ }^{5}$ Genetic changes appear to be the major risk factor that is around $41-42 \%$. The diagnosis of MDD is done on the basis of experience of person and examination of mental status. There is no a laboratory investigation or tests that can be used to diagnose MDD but some of the testing can be done to find out some of the physical conditions that can leads to similar symptoms. MDD should be surely differentiated from sadness because sadness is a normal part of everyone's life and is not severe. ${ }^{1}$ The United States Preventive Services Task 
Force (USPSTF) had set some screening tests for MDD among the age of 12 years but a cochrane review estimated that the daily screening by using questionnaires is not that much effective in detection and treatment of MDD. A person with depression usually exhibits a low mood which relates to all parts of life and an insufficiency of enjoyable experiences. ${ }^{7}$ Depressed people may get inappropriate regret, hopelessness, worthlessness, helplessness and self hatred. In critical condition patient can also have episodes and symptoms of psychosis which includes hallucinations, delusions. ${ }^{12}$ The patients can also have poor concentration and memory problems, reduced sex drive, withdrawal or not like any social situations and activities, irritability and suicidal thoughts. Insomnia is most common in MDD's patient that is in a typical pattern as a person will wake up very early in the morning and could not sleep after that. On other hand hyperinsomnia can also occur. ${ }^{3}$

Antidepressants are the medication used to treat MDD and some other conditions that includes anxiety disorders, dysthmia, obsessive-compulsive disorder, neuropathic pain, eating disorders, sleep disorders etc. ${ }^{8}$ Antidepressants can be given alone or in combination with other drug. The most important classes of antidepressants are the tricyclic antidepressants (TCAs), selective serotonin reuptake inhibitors (SSRIs), monoamine oxidase inhibitors (MAOIs), the serotoninnorepinephrine reuptake inhibitors (SNRIs), tetracyclic antidepressants (TeCAs), noradrenergic and specific serotonergic antidepressant (NaSSAs) and reversible inhibitors of monoamine oxidase A (RIMAs). ${ }^{15}$ Among these classes of antidepressants the TCAs, SSRIs, SNRIs and MAOIs are basically used in MDD.

The TCAs are the medications that can be used basically in mood disorders such as clinical depression, Attention-deficit hyperactivity disorder and chronic pain etc. $^{2}$ The discovery of TCAs had done in 1950 and after the structure of TCAs that includes 3 atom rings it was given the name of tricyclics. Examples of TCAs are amitriptyline, clomipramine, amoxapine, imipramine nortriptyline anddoxepin. The SSRIs are the class of drugs that are majorly used in the treatment of MDD. They work by increasing the extracellular level of the neurotransmitter serotonin in the syneptic cleft that will be available to bind to the postsynaptic receptor. Examples of SSRIs are escitalopram, fluvoxamine, paroxetine, sertraline, fluoxetine and citalopram. ${ }^{9}$ MAOIs are the group of medication that works by inhibiting the action of Monoamine oxidase enzymes that are monoamine oxidase A (MAO-A) and monoamine oxidase B (MAO-B). Examples of MAOIs are phenelzine, isocarboxazid, selegiline and tranylcypromine. ${ }^{16}$ SNRIs are the drugs that specifically inhibit the reuptake of serotonin and norepinephrine. Examples of SNRIs are duloxetine, desvenlafaxine and venlafaxine. $^{10}$

\section{Materials and Method}

The cost variation of antidepressant medications to treat the MDD manufactured by various pharmaceutical industries of India was analyzed.

In this Study, authors used "Current Index of Medical Specialties" (CIMS) online edition, Drugs.com and Mobile Application of National Pharma Pricing to analyze the cost variation between the marketed brands.

\section{Inclusion Criteria:}

1. Antidepressant drugs that are available as such or having its own individual preparations were taken.

2. The marked preparations that are manufactured by the Indian pharmaceutical industries were taken

3. Antidepressant drugs having all the information regarding them like brand name, cost, formulations, and strength were taken.

4. Only oral formulations of the antidepressant drugs were taken i.e. tablet or capsule.

5. The stripes of 10 drugs were taken for the calculation of the cost.

\section{Exclusion Criteria:}

1. Antidepressant drugs other than the oral formulation are excluded.

2. Antidepressant drugs which are prepared by the same industry are excluded.

3. Acid lowering drugs which are only produced by one industry.

4. Antidepressant drugs that are available as an combination with other drugs are also excluded.

5. Antidepressant drugs which are having improper information regarding Brand name, formulation, cost and strength are excluded.

In this study, the calculation of cost ration is done by dividing the maximum cost of the drug by minimum cost of the drug. The calculation of Cost percentage variation was done by using the following formula: Cost variation $(\%)=\underline{\text { Max. cost }- \text { Min. Cost } \times 100}$ Min. cost

\section{Result}

There are 15 drugs with 63 formulations are available in the marked of India with 1173 brands manufactured by various pharmaceutical industries. After this study it is found that there is a wide variation of cost among the various brands of antidepressant drugs available in the market and the number of brands is more in number.

Among all the antidepressant drugs, the highest cost ratio and percentage cost variation was found for the fluvoxamine $100 \mathrm{mg}$ that is 1:12.274and 1127.495followed by amitriptyline $50 \mathrm{mg}$ [1:5.558and 455.813], Nortriptyline $20 \mathrm{mg}$ [1:5.558and 458.823] and clomipramine $75 \mathrm{mg}$ [1:4.142 and 314.285]. The highest number of brands are of escitalopram $10 \mathrm{mg}$ [98] followed by Sertraline $50 \mathrm{mg}$ [63] and Paroxetine $37.5 \mathrm{mg}$ [56]. (Table 1) 
Table 1

\begin{tabular}{|c|c|c|c|c|c|c|c|c|}
\hline $\begin{array}{c}\text { S. } \\
\text { no. }\end{array}$ & Drug Name & $\begin{array}{c}\text { No. of } \\
\text { Brands }\end{array}$ & $\begin{array}{c}\text { Dosage } \\
\text { form }\end{array}$ & Strength & $\begin{array}{c}\text { Minimum } \\
\text { Cost in Indian } \\
\text { Rupees (INR) }\end{array}$ & $\begin{array}{c}\text { Maximum } \\
\text { Cost in Indian } \\
\text { Rupees (INR) }\end{array}$ & $\begin{array}{c}\text { Cost } \\
\text { Ratio }\end{array}$ & $\begin{array}{c}\text { Percentage } \\
\text { cost variation } \\
(\%)\end{array}$ \\
\hline \multirow[t]{4}{*}{1.} & \multirow[t]{4}{*}{ amitriptyline } & 46 & Tablet & $10 \mathrm{mg}$ & 11.9 & 45 & 3.781 & 278.151 \\
\hline & & 50 & Tablet & $25 \mathrm{mg}$ & 14.81 & 44.1 & 2.977 & 197.771 \\
\hline & & 21 & Tablet & $50 \mathrm{mg}$ & 21.5 & 119.5 & 5.558 & 455.813 \\
\hline & & 24 & Tablet & $75 \mathrm{mg}$ & 28.85 & 54.92 & 1.903 & 90.363 \\
\hline \multirow[t]{2}{*}{2.} & \multirow[t]{2}{*}{ Amoxapine } & 5 & Tablet & $50 \mathrm{mg}$ & 38.76 & 99 & 2.554 & 155.417 \\
\hline & & 6 & Tablet & $100 \mathrm{mg}$ & 72.57 & 136.02 & 1.874 & 87.432 \\
\hline \multirow[t]{4}{*}{3.} & \multirow[t]{4}{*}{ Clomipramine } & 8 & Tablet & $10 \mathrm{mg}$ & 16.6 & 24.47 & 1.474 & 47.409 \\
\hline & & 16 & Tablet & $25 \mathrm{mg}$ & 20.02 & 54.08 & 2.701 & 170.129 \\
\hline & & 15 & Tablet & $50 \mathrm{mg}$ & 60.06 & 109 & 1.814 & 81.485 \\
\hline & & 14 & Tablet & $75 \mathrm{mg}$ & 35 & 145 & 4.142 & 314.285 \\
\hline \multirow[t]{4}{*}{4.} & \multirow[t]{4}{*}{ doxepine } & 5 & Capsule & $10 \mathrm{mg}$ & 14.28 & 49.5 & 3.466 & 246.638 \\
\hline & & 6 & Capsule & $25 \mathrm{mg}$ & 24 & 80.5 & 3.354 & 235.416 \\
\hline & & 5 & Tablet & $25 \mathrm{mg}$ & 30 & 75 & 2.5 & 150 \\
\hline & & 4 & Capsule & $75 \mathrm{mg}$ & 60 & 116 & 1.933 & 93.33 \\
\hline \multirow[t]{2}{*}{5.} & \multirow[t]{2}{*}{ Imipramine } & 7 & Tablet & $50 \mathrm{mg}$ & 16.4 & 48.28 & 2.943 & 194.39 \\
\hline & & 4 & Capsule & $75 \mathrm{mg}$ & 27.7 & 47.5 & 1.714 & 71.48 \\
\hline \multirow[t]{3}{*}{6.} & \multirow[t]{3}{*}{ Nortriptyline } & 13 & Tablet & $25 \mathrm{mg}$ & 17 & 95 & 5.558 & 458.823 \\
\hline & & 3 & Tablet & $50 \mathrm{mg}$ & 30.75 & 60 & 1.951 & 95.121 \\
\hline & & 3 & Tablet & $75 \mathrm{mg}$ & 42.5 & 90 & 2.117 & 111.964 \\
\hline \multirow[t]{3}{*}{7.} & \multirow[t]{3}{*}{ Escitalopram } & 92 & Tablet & $5 \mathrm{mg}$ & 26 & 69.9 & 2.688 & 168.846 \\
\hline & & 98 & Tablet & $10 \mathrm{mg}$ & 49.47 & 95.98 & 1.94 & 94.016 \\
\hline & & 69 & Tablet & $20 \mathrm{mg}$ & 76.18 & 146 & 1.916 & 91.651 \\
\hline \multirow[t]{2}{*}{8.} & \multirow[t]{2}{*}{ Fluvoxamine } & 25 & Tablet & $50 \mathrm{mg}$ & 13 & 125 & 9.615 & 861.538 \\
\hline & & 19 & Tablet & $100 \mathrm{mg}$ & 18.33 & 225 & 12.274 & 1127.495 \\
\hline \multirow[t]{3}{*}{9.} & \multirow{3}{*}{ Paroxetine } & 29 & Tablet & $12.5 \mathrm{mg}$ & 75 & 109 & 1.453 & 45.333 \\
\hline & & 36 & Tablet & $25 \mathrm{mg}$ & 118 & 143 & 1.211 & 21.186 \\
\hline & & 56 & Tablet & $37.5 \mathrm{mg}$ & 132 & 190 & 1.439 & 43.939 \\
\hline 10. & Sertraline & 43 & Tablet & $25 \mathrm{mg}$ & 17 & 32.4 & 1.905 & 90.588 \\
\hline & & 63 & Tablet & $50 \mathrm{mg}$ & 25 & 45 & 1.8 & 80 \\
\hline & & 33 & Tablet & $100 \mathrm{mg}$ & 44 & 89.6 & 2.036 & 103.636 \\
\hline 11. & Fluoxetine & 17 & Tablet & $10 \mathrm{mg}$ & 21 & 30 & 1.428 & 42.857 \\
\hline & & 23 & Tablet & $20 \mathrm{mg}$ & 26.85 & 52.8 & 1.966 & 96.648 \\
\hline 12. & Citalopram & 8 & Tablet & $5 \mathrm{mg}$ & 30.6 & 44.63 & 1.458 & 45.849 \\
\hline & & 32 & Tablet & $20 \mathrm{mg}$ & 37.5 & 124.74 & 3.326 & 232.64 \\
\hline & & 16 & Tablet & $40 \mathrm{mg}$ & 47.38 & 118 & 2.49 & 149.05 \\
\hline 13. & Venlafaxine & 5 & Tablet & $25 \mathrm{mg}$ & 12.82 & 29.4 & 2.293 & 129.329 \\
\hline & & 17 & Tablet & $37.5 \mathrm{mg}$ & 20.96 & 51.47 & 2.455 & 145.562 \\
\hline & & 7 & Capsule & $37.5 \mathrm{mg}$ & 19.48 & 52 & 2.669 & 166.94 \\
\hline & & 20 & Tablet & $75 \mathrm{mg}$ & 38.2 & 100.93 & 2.642 & 164.214 \\
\hline & & 8 & Capsule & $75 \mathrm{mg}$ & 38 & 76 & 2 & 100 \\
\hline & & 16 & Tablet & $150 \mathrm{mg}$ & 81.9 & 130 & 1.587 & 58.73 \\
\hline & & 12 & Capsule & $150 \mathrm{mg}$ & 85 & 136 & 1.6 & 60 \\
\hline 14. & Desvenlafaxine & 36 & Tablet & $50 \mathrm{mg}$ & 74.28 & 131.39 & 1.768 & 76.884 \\
\hline & & 30 & Tablet & $100 \mathrm{mg}$ & 129 & 238.37 & 1.847 & 109.37 \\
\hline 15. & Duloxetine & 15 & Capsule & $20 \mathrm{mg}$ & 38.5 & 83 & 2.155 & 115.584 \\
\hline & & 25 & Tablet & $20 \mathrm{mg}$ & 42.72 & 80.93 & 1.894 & 89.422 \\
\hline & & 13 & Capsule & $30 \mathrm{mg}$ & 52.87 & 123 & 2.326 & 132.646 \\
\hline & & 21 & Tablet & $30 \mathrm{mg}$ & 62.18 & 122.87 & 1.976 & 97.603 \\
\hline & & 10 & Capsule & $40 \mathrm{mg}$ & 39.59 & 127 & 3.207 & 220.788 \\
\hline & & 9 & Tablet & $40 \mathrm{mg}$ & 87 & 142.8 & 1.641 & 64.137 \\
\hline & & 7 & Capsule & $60 \mathrm{mg}$ & 110 & 170 & 1.545 & 54.545 \\
\hline & & 8 & Tablet & $60 \mathrm{mg}$ & 102.86 & 186 & 1.808 & 80.828 \\
\hline
\end{tabular}

\section{Conclusion}

After conducting this study analysis we concluded that there is lots of variations interm of cost and existence of many brands of antidepressant drugs in
Indian market. This variation could be minimized by using the prescribe drugs with generic name not by the particular name. Also this will be suitable economically by selecting brands of drugs having low maximum 
retail price (MRP) by the pharmacist. This study is useful pharmacoeconomic measure that could help to reduce the cost of illness to patients.

Funding: No funding sources are provided to authors. Conflict of interest: All the authors are having no conflict of interest.

Ethical approval: Ethical approval is not necessary for our study.

\section{References}

1. Avenevoli S, Swendsen J, He JP, Burstein M and Merikangas KR. Major depression in the National Comorbidity Survey-Adolescent Supplement: prevalence, correlates, and treatment. Journal of the American Academy of Child \& Adolescent Psychiatry2015; 54(1): pp.37-44.

2. Carson VB. Mental health nursing: the nurse-patient journey W.B. Saunders2000; pp. 423.

3. Chung KF, Yeung WF, Yu YM, Yung KP, Zhang SP, Zhang ZJ, Wong MT, Lee WK and Chan LW.

Acupuncture for residual insomnia associated with major depressive disorder: a placebo-and sham-controlled, subject-and assessor-blind, randomized trial. The Journal of clinical psychiatry2015; 76(6): pp.e752-60.

4. David D, Cristea IA, Beck AT, Jay Lynn S and H Montgomery G. Varieties of Psychotherapy for Major Depressive Disorder in Adults. Evidence-Based Psychotherapy: The State of the Science and Practice2018; pp.11-36.

5. Goldstein BI, Carnethon MR, Matthews KA, McIntyre RS, Miller GE, Raghuveer G, Stoney CM, Wasiak H and McCrindle BW. Major depressive disorder and bipolar disorder predispose youth to accelerated atherosclerosis and early cardiovascular disease: a scientific statement from the American Heart Association. Circulation2015;132(10): pp.965-86.

6. Kupferberg A, Bicks L and Hasler G. Social functioning in major depressive disorder. Neuroscience \& Biobehavioral Reviews2016;69: pp.313-32.

7. Lentz C. Anxiety and Mood Disorders in an Emergency Context. Big Book of Emergency Department Psychiatry: A Guide to Patient Centered Operational Improvement 2017.

8. Lozano AM and Mayberg HS. Functional Neuromodulation Inc, Method of treating cognitive disorders using neuromodulation. U.S. Patent Application 2016; 14/586:849.

9. Preskorn SH, Ross R, Stanga CY. "Selective Serotonin Reuptake Inhibitors". In Sheldon H. Preskorn, Hohn P. Feighner, Christina Y. Stanga, Ruth Ross. Antidepressants: Past, Present and Future. Berlin: Springer 2004; pp. 241-62.

10. Stahl SM, Grady MM, Moret C and Briley M. SNRIs: the pharmacology, clinical efficacy, and tolerability in comparison with other classes of antidepressants. CNS spectrums2005; 10(9): pp.732-47.

11. Thomas SJ, Shin M, McInnis MG and Bostwick JR. Combination Therapy with Monoamine Oxidase Inhibitors and Other Antidepressants or Stimulants: Strategies for the Management of Treatment Resistant Depression. Pharmacotherapy: The Journal of Human Pharmacology and Drug Therapy2015; 35(4): pp.433-49.

12. Toh WL and Thomas N. SU111. A Comprehensive Phenomenological Examination of Auditory Verbal Hallucinations (AVHs): A Comparison of Mood vs
Psychotic Disorders. Schizophrenia bulletin 2017;43(Suppl 1): p.S201.

13. Turecki G and Brent DA. Suicide and suicidal behaviour. The Lancet2016; 387(10024): pp.1227-1239.

14. Vishwakarma V, Prakash, C and Barua MK. A fuzzybased multi criteria decision making approach for supply chain risk assessment in Indian pharmaceutical industry. International Journal of Logistics Systems and Management2016;25(2): pp.245-65.

15. Wong J, Motulsky A and Tamblyn R. Trends in Prescribing of Antidepressants for Depression and Offlabel Indications. Pharmacoepidemiology and Drug Safety2015;24: p.398.

16. Yamada $\mathrm{M}$ and Yasuhara H. Clinical pharmacology of MAO inhibitors: safety and future. Neurotoxicology2004;25(1-2): pp.215-21. 